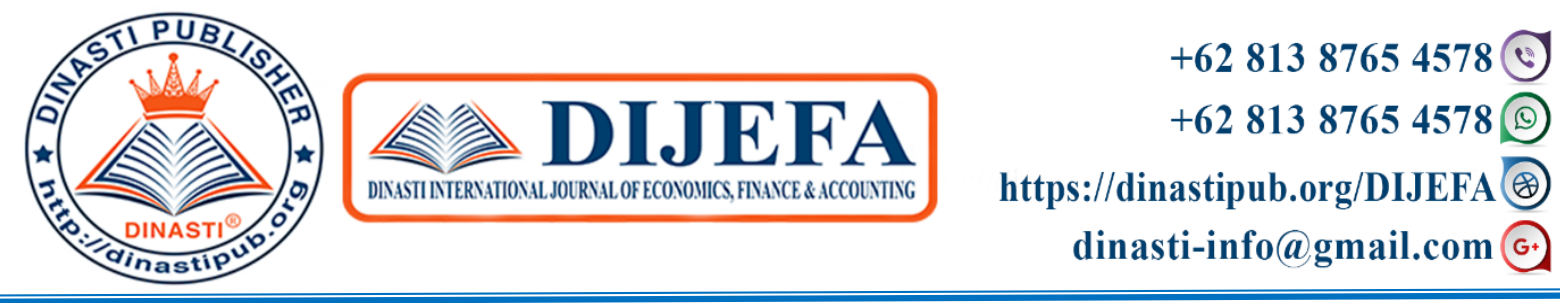

\title{
DETERMINANT ANALYSIS OF FINANCIAL SECTOR STOCK IN INDONESIA
} STOCKS EXCHANGE

\author{
Liza Yusmia ${ }^{1)}$, Abitur Asianto ${ }^{2)}$ \\ ${ }^{1,2)}$ Mercu Buana University, Jakarta, Indonesia
}

\begin{tabular}{|c|c|}
\hline $\begin{array}{l}\text { Corresponding author: First } \\
\text { Author } \\
\text { E-mail: } \\
{ }^{1)} \underline{\text { lizayusmia @ gmail.com }} \\
\text { 2) abitur.asianto@ mercubuana.ac.id }\end{array}$ & $\begin{array}{l}\text { Abstract: These research had purposed to examine } \\
\text { related to macroeconomic variables on financial sector } \\
\text { stock index in Indonesia Stock Exchange. This research } \\
\text { used Vector Error Correction Model (VECM) method } \\
\text { with monthly data from financial sector stock index as } \\
\text { the dependent variable and the GDP quarterly data, as } \\
\text { well as monthly data on inflation, BI interest rates, } \\
\text { exchange rates, the Fed interest rate, gold prices, oil } \\
\text { prices,and also the S\&P 500 index as independent } \\
\text { variable with data range from January } 2014 \text { to August } \\
\text { 2019. These results that obtained from this research } \\
\text { were the shocks in BI interest rate variable and the } \\
\text { exchange rate which have positive responses in the long } \\
\text { term, while the GDP, inflation, and Fed interest rates, } \\
\text { gold prices, oil prices, and the S\&P 500 index } \\
\text { responded negatively in the long term by the financial } \\
\text { sector stock index. Beside that, the BI interest rate } \\
\text { variable has the greatest contribution in changed of } \\
\text { financials stock index. }\end{array}$ \\
\hline
\end{tabular}

\section{INTRODUCTION}

Financial sector is the dominant sector which influencing Indonesia's macroeconomics because of its price shocks would have an impact to Indonesian economy generally. Financial index volatility had significant impact on Indonesia's domestic macroeconomic volatility. According to Maulana, et al et al. (2015) Global financial crisis that occurred in 2008 had quite negative impact on banking sector in Indonesia. The declined in some of financial sector stock 
prices at that time was due to an increase in capital outflows from Indonesia, as reflected of declined on foreign ownership in SBIs, SUN and stocks in capital market, including banking stocks in Indonesia that reach the peaked on November 2008.

At the start of economic crisis in 2008, the first thing that Indonesia felt was the fall in the rupiah exchange rate against US dollar. As result, there so many banks suffered from losses, especially banks that had loans in foreign currency and did not hedge their loans. Beside that, problems with banks' cash have caused banks to face liquidity problems which resulted in banks losing confidence and people were busy withdrawing their money on a large scale from banks (Bank Indonesia, 2010).

The movement from Financial Sector stock index has continued to increase during these last 10 years. From data obtained, it could be seen that Financial Sector is the sector which experienced the most significant increase from 2010 to 2019 compared to other sectors.

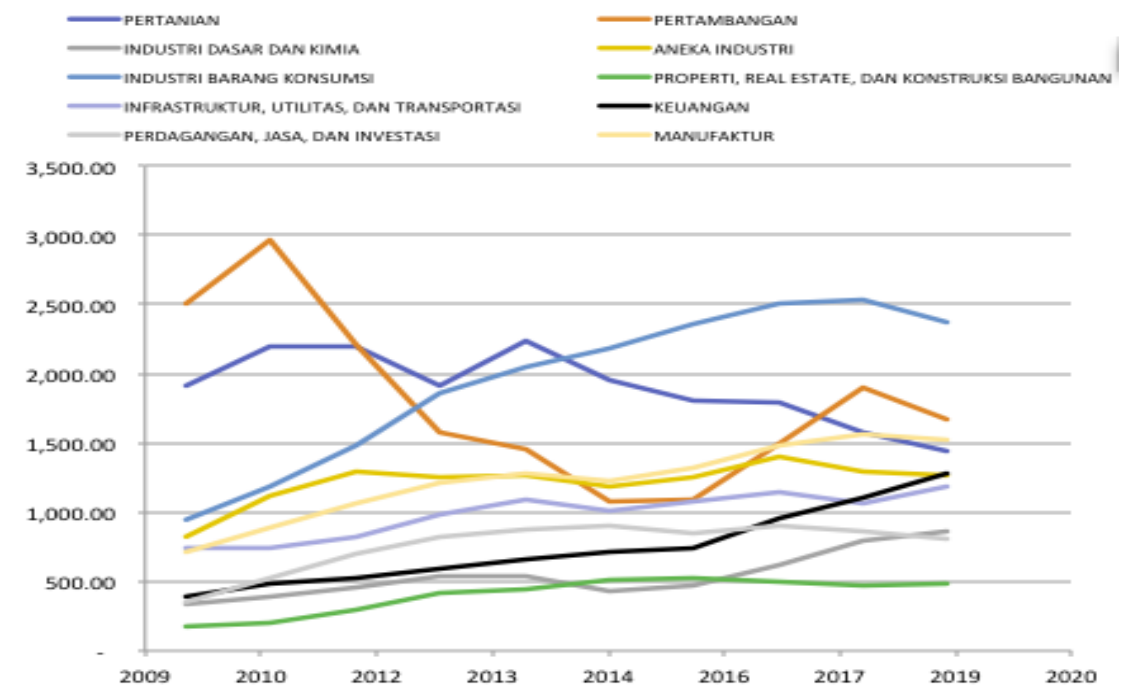

Figure 1. Comparison of Stock Indexs of each Sector for 10 years

Source: $\underline{w w w . i n v e s t i n g . c o m ~(d a t a ~ p r o c e s s e d) ~}$

According to these data obtained, Financial Sector had total return of $129 \%$ in the first position, then the Property, Real Estate and Building Construction Sector of $119 \%$ in the second position. From an investor's perspective, surely means if Financial Sector could be a good choice to invest. 


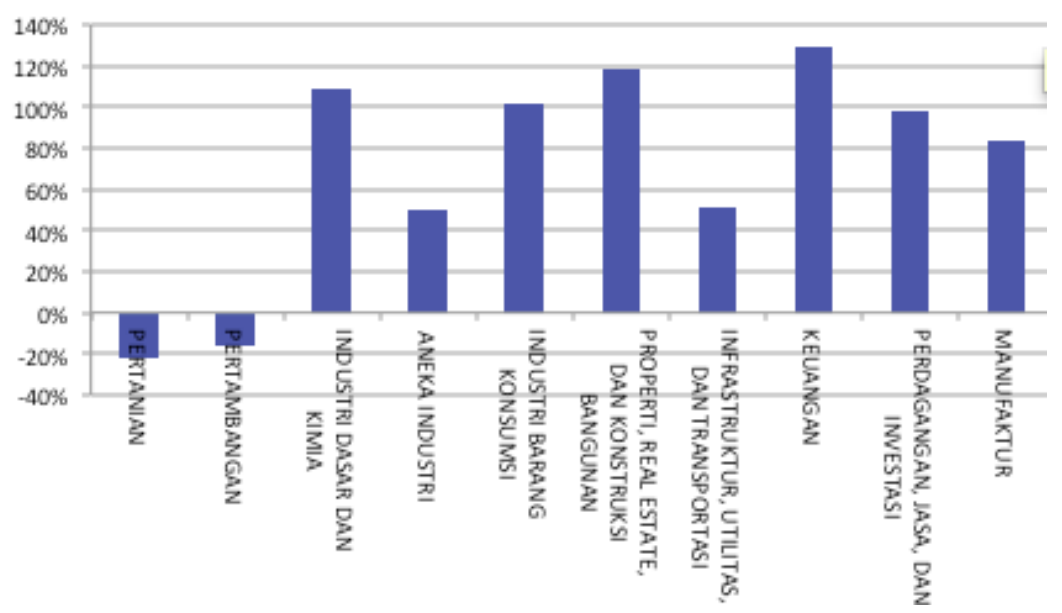

Figure 2. Total Return of Stocks per Sector

Source: $\underline{\text { www.investing.com (data processed) }}$

In several research that have been reported, there are macroeconomic factors from inside and outside Indonesia which could impact the index of stock. However, soAmetimes the research results did not support one to another. Among them were Maulana, et al (2015) which stated that Indonesia's GDP had significant impact on banking stock prices, while according to Kewal (2012) stated that Indonesia's GDP did not have significant influence on IDX composite. Miyanti and Wiagustini (2018) and Kewal (2012)were also stated that the inflation had no impact on IDX composite while Misgiyanti (2009) argues that inflation had significant negative influence on property sector stock index.

According to Maulana, et al, (2015), BI interest rates had influence towards bank stocks prices. Widodo, et al (2017) were defined that BI interest rate had significant influence on the IDX composite. Amarasinghe (2015) were also has the same opinion, that interest rates had negative significant impact on stock prices. Meanwhile, Sihombing (2014) stated that BI interest rate was the most dominant variable which had negative influence on IDX composite for long term. Miyanti and Wiagustini (2018) revealed that Fed's interest rate had positive significant impact on IDX composite Meanwhile, Misgiyanti (2009) stated that Fed's interest rate had negative impact towards IDX composite.

Oktarina (2016) defined that gold prices had positive impact on the IDX composite movement, while according to Satyatama and Sumantyo (2017), gold prices had negative and significant influence on mining sector stock index. According to Widodo, et al. (2017), the S\&P 500 did not have significant influence on IDX composite but then based on Irwanto and Narsa (2016) stated that the S\&P 500 index had positive impact towards it.

Seeing at these phenomenon above, namely the high return of financial sector compared to others . It makes attractive as a place to invest, it is necessary to carry out more in-depth analysis of determinants factors towards financial sector stock index. Beside that, there are still have the differences of opinion in prior research, so there appears those various inputs to 
develop this research by adding other macroeconomic factors which have an influence on the stock index, especially from financial sector, such as third party funds (supply) and credit to third parties (demand).

\section{LITERATURE REVIEW}

\section{Capital Market}

The capital market is a market for long-term financial variety which tradable financial instruments. Capital market means of funding for companies and other institutions (such as the government) and as a place for investing activities.

\section{Efficient Market Hypothesis (EMH)}

According to Fama (1970), the ideal capital market is one whose prices provide accurate signals for resource allocation. Furthermore, she said that the efficient market form could be identified into 3 (three) that are known as the "efficient market hypothesis", such as : weak form of the efficient market hypothesis, semi-strong form of the efficient market hypothesis, and strong form of the efficient market hypothesis.

\section{Stock}

Stocks are one of the most popular instruments in financial market. Stock could be interpreted as a sign of the capital participation from person or party (business entity) in a company or limited liability company. By including capital, the party could claim on company income, company assets, and entitled to attend the General Meeting of Shareholders (GMS).

\section{Financial Sector}

Financial sector is one of sectors at Indonesia Stock Exchange. Businesses related to the financial sector are financial intermediaries, financial institutions, insurance companies, securities companies and investment companies. Financial Sub-Sector consists of Banks, financial institutions, securities companies, insurance and others.

\section{Gross Domestic Product (GDP)}

Gross Domestic Product (GDP) is production of goods and services in an economic area within certain time interval measured in the concept of value added (value added) created by economic sectors in the region in total. GDP can be used as an indicator to measure the economic performance of a country or as a reflection of the success of a government in driving economic sectors.

\section{Inflation}

According to Nanga (2005), inflation is a symptom in which the general price level has increased continuously. An increase in the price of one or two goods alone cannot be called inflation, unless it expands or results in increasing prices of another good. These indicator 
which often used to measure rate of inflation is the Consumer Price Index (CPI). Changed in the CPI from time to time was indicated that price movements of packages of goods and services consumed by publics.

\section{Bank Indonesia Interest Rates}

$\mathrm{BI}$ interest rate is a policy interest rate that reflects the monetary policy stance or stance set by Bank Indonesia and announced to the public. BI interest rates are announced by the Board of Governors of Bank Indonesia at every monthly Board of Governors Meeting (Bank Indonesia, 2016).

\section{Exchange Rate}

According to KBBI, the exchange rate is the value of a country's currency which stated in the value of another country's currency. Exchange rates can undergo two changes, which is when there has an increase in the value of one's own currency against foreign currency (appreciation) and when there has decrease in the value of its own currency against foreign currency (depreciation).

\section{The Fed Interest Rate}

Fed interest rate is a popular term for federal Reserve Banks which is the central bank of United States. If the Fed's interest rate arises, there has concern that foreign investor funds will leave the developing countries, including Indonesia. This will causing the idx composite to weaken in the short term (Miyanti, 2018).

\section{Gold Price}

London Fixings: London Bullion Market Association (LBMA) sets levels per troy ounce. The fix price of gold was determined by arranging the bids until supply and demand were matched. At this point the price is announced as a 'Fixed' price for gold and all business that conducted based on that price.

\section{Crude Oil Price}

Crude oil is commodity and source of energy which most needed by all countries in the world. The world crude oil price (crude oil price) is measured by the spot price of world oil that used as standard is West Texas Intermediate (WTI) and Brent. In this research were using the WTI price because it has the best quality crude oil.

\section{S\&P 500 Index}

S\&P stands for Standard and Poor's. This index includes 500 companies whose stocks are traded on NYSE or NASDAQ. The components of S\&P 500 were selected by committee which work under certain criteria. According to Widodo, et al (2017) The Standard \& Poor's 500 
Index is one of the largest stock indexs in the world. Therefore, the movement of S\&P 500 index could affect almost all stock indexs in the world, including the IDX composite.

\section{Conceptual Framework and Hypothesis}

These conceptual framework and hypothesis from this research could be drawn as follows:

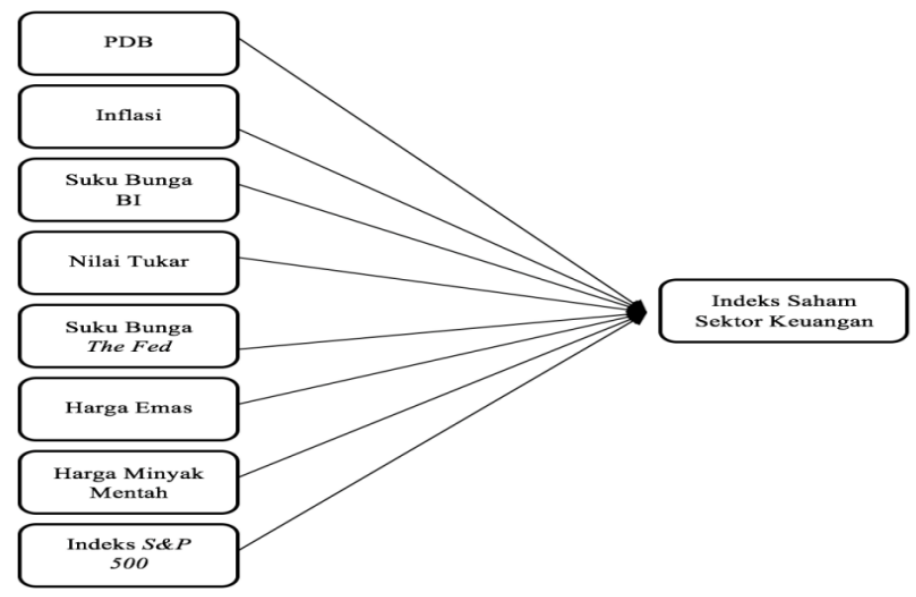

Figure.3 Conceptual Framework

H1: Gross Domestic Product had positive impact on financial sectors stock price index.

H2: Inflation had negative impact on financial sector's stock price index.

H3: BI interest rates had negative impact on financial sector's stock price index.

H4: Exchange rate had negative impact on financial sector's stock price index.

H5: Fed's interest rate had negative impact on financial sector's stock price index.

H6: gold price had negative influence on financial sector' stock price index.

H7: Crude oil price had positive impact towards financial sector' stock price index.

H8: S\&P 500 index had positive impact towards financial sector'stock price index.

\section{RESEARCH METHODS}

These research type was quantitative research with Vector Auto Regression (VAR) Vector Error Correction Model (VECM) approach to proved and analyzed those inter-variable influence of GDP, inflation, BI interest rates, exchange rates, Fed's interest rate, gold prices, oil prices and S\&P 500 index towards financial sector' stock price index. These research population were the stock index from financial sector, GDP, inflation, BI interest rates, 
exchange rates, Fed's rates, gold prices, crude oil prices and S\&P 500 index. While the sample in this research was the monthly value of financial sector' stock index, inflation, BI interest rate, exchange rate, The Fed's interest rate, gold price, crude oil price and S\&P 500 index, as well as GDP quarterly value with range from June 2014 to August 2019.

This research used secondary data in form of monthly and quarterly data which announced to the public by collecting, recording and reviewing them. These data was in form of time series data from January 2014 to August 2019. Data analysis method used for time series data in this research was Vector Autoregression (VAR) approach if the data used was stationary and not cointegrated or the Vector Error Correction Model (VECM) if the data were not stationary at the level but stationary in the first difference and potentially cointegrated.

\section{RESULTS AND DISCUSSION}

\section{Stationarity Test}

According to the results from unit root test using Augmented Dickey Fuller (ADF), it shows that all variables were not stationary at the level but Stationary at the first difference level, except for the interest rate of The Fed (SBTF). After it was found that there has data that were instationary at the first difference level, then each data stationarity was re-tested at the second difference level and it was found that whole variables were stationary.

\section{Table 1. Recapitulation of Stationarity Test Results}

\begin{tabular}{lclclcl}
\hline \multirow{2}{*}{ Variable } & \multicolumn{2}{c}{ Level } & \multicolumn{2}{c}{ First Difference } & \multicolumn{2}{c}{ Second Difference } \\
\cline { 2 - 7 } & P-value & Information & P-value & Information & P-value & Information \\
\hline ISSK & 0.7970 & Instationary & 0.0000 & Stationary & 0.0000 & Stationary \\
PDB & 0.9489 & Instationary & 0.0000 & Stationary & 0.0000 & Stationary \\
INFL & 0.1658 & Instationary & 0.0000 & Stationary & 0.0000 & Stationary \\
SBBI & 0.6781 & Instationary & 0.0000 & Stationary & 0.0000 & Stationary \\
KURS & 0.5063 & Instationary & 0.0000 & Stationary & 0.0000 & Stationary \\
SBTF & 0.7776 & Instationary & 0.2523 & Instationary & 0.0000 & Stationary \\
GOLD & 0.5047 & Instationary & 0.0000 & Stationary & 0.0000 & Stationary \\
WTI & 0.2465 & Intationary & 0.0000 & Stationary & 0.0000 & Stationary \\
ISP5 & 0.7569 & Instationary & 0.0000 & Stationary & 0.0000 & Stationary \\
\hline
\end{tabular}

*Stationary with P-value $<5 \%$

\section{VAR Stability Analysis}

From these VAR stability test result, it could be concluded that the VAR stability estimation that used was IRF and FEVD analysis which has been stable because all of its roots have modulus smaller than one with the maximum lag being in lag 3 . This could be seen from all inverse roots of AR characteristic polynomial which inside these circle unit. 


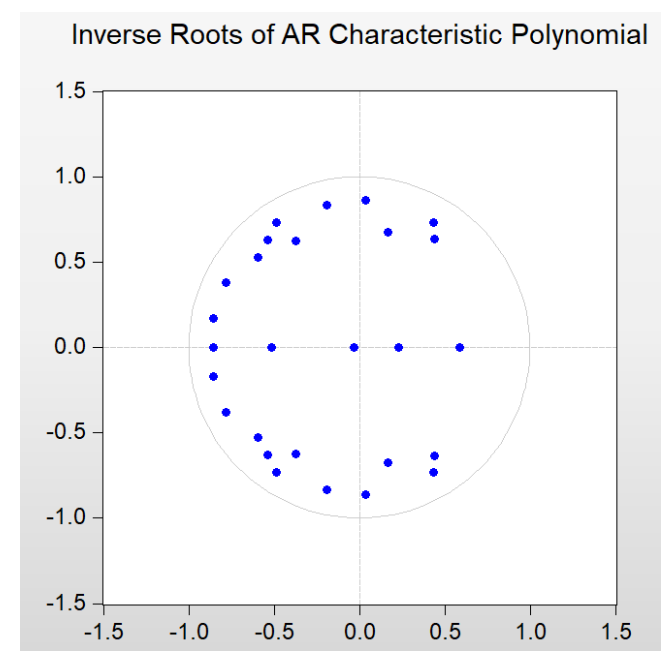

Figure 4.Inverse Roots of AR Characteristic Polynomial

\section{Optimum Lag Test}

Based on these VAR stability test, the maximum lag from VAR model was 3. From these maximum lag amount obtained, the optimum lag amount will be determined. The determination of these optimum lag in this research based on the lag that has code *, which means that lag was chosen by the most by these criterions which is lag 3 .

Table 2. Optimum Lag Test Results

\begin{tabular}{lllllll}
\hline \hline Lag & LogL & LR & FPE & AIC & SC & \multicolumn{1}{l}{ HQ } \\
\hline \hline 0 & 915.1285 & NA & $2.60 \mathrm{e}-24$ & -28.76598 & $-28.45982 *$ & -28.64557 \\
1 & 1062.257 & 247.5501 & $3.26 \mathrm{e}-25$ & -30.86531 & -27.80369 & -29.66116 \\
2 & 1176.897 & 160.1312 & $1.30 \mathrm{e}-25$ & -31.93323 & -26.11615 & -29.64534 \\
3 & 1294.663 & $130.8509 *$ & $6.21 \mathrm{e}-26 *$ & $-33.10040 *$ & -24.52786 & $-29.72878 *$ \\
\hline \hline
\end{tabular}

* indicates lag order selected by the criterion

LR: sequential modified LR test statistic (each te st at $5 \%$ level)

FPE: Final prediction error

AIC: Akaike information criterion

SC: Schwarz information criterion

HQ: Hannan-Quinn information criterion

\section{Cointegration Test}

From these cointegration test result, it could be seen that there are 9 cointegration relationships shown in the trace statistic value which greater than critical value and probability value which is below $<0.05$. Thus, these VAR model above could be developed into VECM model. 
Table 3. Cointegration Test Results

\begin{tabular}{|c|c|c|c|c|}
\hline $\begin{array}{l}\text { Hypothesized } \\
\text { No. of } \mathrm{CE}(\mathrm{s})\end{array}$ & Eigenvalue & $\begin{array}{l}\text { Trace } \\
\text { Statistic }\end{array}$ & $\begin{array}{l}0.05 \\
\text { Critical Value }\end{array}$ & Prob.** \\
\hline None* & 0.916741 & 647.9410 & 179.5098 & 0.0000 \\
\hline At most $1 *$ & 0.798935 & 488.8495 & 143.6691 & 0.0000 \\
\hline At most $2 *$ & 0.695786 & 386.1853 & 111.7805 & 0.0000 \\
\hline At most $3^{*}$ & 0.662264 & 310.0237 & 83.93712 & 0.0000 \\
\hline At most $4^{*}$ & 0.644389 & 240.5522 & 60.06141 & 0.0000 \\
\hline At most $5^{*}$ & 0.602652 & 174.3814 & 40.17493 & 0.0001 \\
\hline At most $6^{*}$ & 0.486177 & 115.3130 & 24.27596 & 0.0000 \\
\hline At most $7^{*}$ & 0.451747 & 72.69687 & 12.32090 & 0.0000 \\
\hline At most $8^{*}$ & 0.414254 & 34.23167 & 4.129906 & 0.0000 \\
\hline
\end{tabular}

Trace test indicates 9 cointegrating eqn(s) at the 0.05 level

* denotes rejection of the hypothesis at the 0.05 level

**MacKinnon-Haug-Michelis (1999) p-values

\section{VECM Estimation Results}

The short-term VECM estimation results shows that there has an error correction of 0.035137. This figure was not statistically significant. Meaning that imbalance (disequilibrium) will be corrected by 0.035137 in these short term for next period. In the short term, which is the monthly data during period of January 2014 to August 2019, these variable of Gross Domestic Product (GDP) at lag 2, Indonesian bank interest rate (SBBI) at lag 1, 2, 3, and exchange rate (KURS) at lag 3 which have significant impact on financial sector stock index. Which shown by the T-statistic value that bigger than the T-table value. Meanwhile, the inflation variable (INFL), the Fed interest rate (SBTF), gold price (GOLD), oil price (WTI), S\&P 500 index (ISP5) have no impact towards financial sector stock index. This indicated by T-statistic value which smaller than the T-Table value.

In the long run, these variables of GDP, inflation and S\&P 500 index will have significant impact on financial sector stock index. This indicated by T-statistic value of these variable which greater thanT-table value. Meanwhile, BI interest rate (SBBI), exchange rate (KURS), Fed interest rate (SBTF), gold price (GOLD) and oil price (WTI) have no impact towards financial sector stock index in the long run. This indicated by the amount of T-statistic value of these variable which is less than T-table value.

\section{Impulse Response Function (IRF) Analysis}

The response from financial sector stock index towards shocks on GDP which indicated that unstable shocks, rising and falling alternately, occurring in the first of nine periods and being stable in the long term. This means that if the amount of GDP increases, the financial sector stock index will respond negatively, which is, the financial sector stock index will declined. The response from these financial sector stock index in shocks of inflation shows that the shocks that occur were very unstable, both short and long term. That means if inflation 
increases, the financial sector stock index will respond negatively, which is a decline in financial sector stock index.

The response of financial sector stock index to shocks on BI interest rate that indicates if BI interest rate increases, it will be followed by an increase in financial sector stock index. These response of financial sector stock index towards shocks on exchange rate shows that financial sector stock index responds positively if there has an shock in exchange rate. Meaning if there has an increasing in exchange rate, then financial sector stock index will also increased.

The response from financial sector stock index on shocks in Fed's interest rate shows that if Fed's interest rate strengthens, the financial sector stock index will weaken. The response of these financial sector stock index on shocks towards gold price shows that in the long term, the financial sector stock index responds negatively. Meaning if the gold price were increased, the stock index of the financial sector will declined aswell.

The response of financial sector stock index on shocks in oil prices shows that in the long run it provides continuous negative response. Thus, it could be concluded that if oil price was increase, it will be followed by an increase in the financial sector stock index. These response of financial sector stock index on shocks in the S\&P 500 index shows that overall, the financial sector stock index responds negatively when there has shock on the S\&P 500 index. Meaning, if there has an increase in S\&P 500 index, the financial sector stock index will declined.
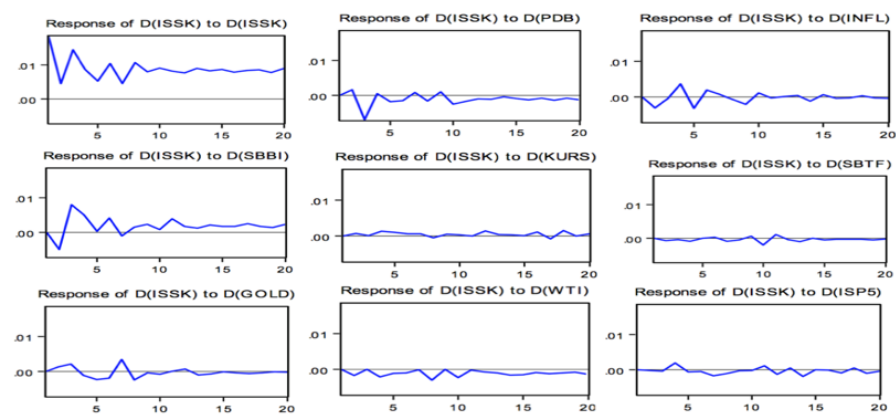

Figure 5. The response of financial sector stock index on shocks towards other variables

\section{Forecasting Error Variance Decomposition (FEVD)}

According to these analysis of Forecasting Error Variance Decomposition, it shows that in the short term of stock index from financial sector will be strongly influenced by stock price index of the financial sector itself. The dominant contribution in changed of stock price index from financial sector in the long term or the twentieth period from estimated FEVD is the financial sector stock index (ISSK) of 80.50 percent, BI interest rate (SBBI) of 8.58 percent, Gross Domestic Product (GDP) 3.66 percent, inflation (INFL) of 2.12 percent, gold price (GOLD) of 1.70 percent, oil price (WTI) of 1.63 percent, S\&P 500 index of 0.79 percent, exchange rate (KURS) of 0.52 percent and Fed interest rates of 0.45 percent. The large contribution of these financial sector stock index itself in the long run means the movement 
from financial sector stock index was influenced by financial performance of companies operational in financial sector itself.

\section{Discussion}

Based on these VECM estimation results, Gross Domestic Product had negative and significant impact in the short term, but had positive and significant impact in the long term on financial sector stock index. Through these IRF analysis it is known that if there has shock occurs in one of standard deviation at GDP, the financial sector stock index will reacted negatively in the long run. Meaning if the amount of GDP increased, financial sector stock index will decreased. Meanwhile, when viewed from the amount of contribution value in changed of financial sector stock index through FEVD analysis, GDP had contribution of 3.66 percent. This amounted was indicates if GDP had an impact towards financial sector stock index.

From these VECM estimation result shows that inflation had negative and insignificant impact in the short term, but had positive and significant impact in the long term towards financial sector stock index. Through these IRF analysis it is known if there has shock occurs in one of standard deviation on inflation, the financial sector stock index will reacted negatively. Meaning if the amount of inflation increases, the financial sector stock index will decreased. This because inflation continuous increase in prices resulting in decreased of purchasing power. By these decline in people's purchasing power, would makes difficult for companies to sell their products so the company's opportunities to earned profits would reduced. Which means if the company's performance decreased which results in decrease of company's stock price and ends in a decline in the stock index. Meanwhile, when viewed from the amount of contribution value in changed of financial sector stock index through FEVD analysis, inflation were contributed of 2.12 percent. This amount was indicated that inflation had impact towards financial sector stock index.

Based on VECM estimation result which have been carried out shows that Bank Indonesia interest rate had positive and significant impact on the short term and had negative but insignificant impact in the long term towards financial sector stock index. Through these IRF analysis it is known that if there has a shock occurs in one of standard deviation on BI interest rate, So Financial sector stock index will reacted positively in the long term. Meaning if $\mathrm{BI}$ interest rate increased, it will be followed by an increase in financial sector stock index. These IRF result were inversely proportional to the existing theory, which told that if BI interest rate has increased the financial sector stock index will decreased Meanwhile, when we viewed from the amount of these contribution value in changed of financial sector stock index through FEVD analysis, BI interest rate had contribution of 8.58 percent. This amounted was indicated that GDP had an impact on financial sector stock index.

Based on these VECM estimation results earned positive and significant exchange rate in the short term and had positive impact in the long term towards financial sector stock index. Through these IRF analysis it is known if there has shock occurs in one of standard deviation 
on the exchange rate, So financial sector stock index will reacted positively in the long term. Meaning if the amount of the exchange rate was increased, the stock index from financial sector will also increase. This IRF result was contradicted to the opinion that an increase in exchange rate will result in decreased of stocks prices. Meanwhile, when viewed from the amount of contribution value in changed of financial sector stock index through FEVD analysis, the exchange rate were contributed to 0.52 percent. This amount was indicated that exchange rate had influence towards financial sector stock index.

From these VECM estimation results, it could be seen that Fed interest rate, in the short and long term, had negative and insignificant impact on financial sector' stock index Through IRF analysis it is known if there has shock occurs in one of standard deviation in Fed's interest rate, the financial sector stock index will react negatively in the long time. Meaning that if the amount of Fed's interest rate increased, the financial sector stock index will decreased. Meanwhile, when viewed from these amount of these contribution value in changed of financial sector stock index through FEVD analysis, the Fed's interest rate was contributed to 0.45 percent. This amount was indicated that Fed's interest rate had affects to financial sector stock rate.

Based on these VECM estimation results, in the short and long term, gold prices had positive and insignificant impact on financial sector stock index through IRF analysis it is known if there has shock occurs in one of standard deviation in gold price, financial sector stock index will reacted negatively in the long run. Meaning if total price increased, the financial sector stock index will decreased. Meanwhile, when viewed from the amount of contribution value in changed of financial sector stock index through FEVD analysis, gold price were contributed to 1.70 percent. This amount was indicated that gold price had impact on financial sector stock index.

From VECM estimation result shows that oil prices had negative and insignificant impact in the short term, but positive and insignificant impact in the long term towards financial sector stock index. Through these IRF analysis it is known that if there has shock occurs in one of standard deviation on the oil price, the financial sector stock index will react negatively in the long run. Meaning if the amount of oil prices increased, the financial sector stock index will decreased. This IRF result was inversely proportional to the hypothesis which stated that an increase in oil prices would affects to increase in the stock index. Meanwhile, if viewed from the amount of contribution value in changed in financial sector stock index through FEVD analysis, the oil price were contributed of 1.63 percent. This value was indicated that oil price had impact to financial sector stock index

Referring to VECM estimation results, S\&P 500 index had negative and insignificant effect in the short term, but negative and significant in the long term towards financial sector stock index. Through these IRF analysis it is known that if there has shock occurs in one of standard deviation on S\&P 500 index, the financial sector stock index will reacted negatively in the long run. Meaning if the number of S\&P 500 index increased, the financial sector stock 
index will decreased. This result was different from hypothesis which has been made that S\&P 500 index had positive impact on financial sector stock index. Meanwhile, when we viewed from the amount of contribution value in changed of financial sector stock index through FEVD analysis, the S\&P 500 index were contribution to 0.79 percent. This amounted were indicated if S\&P 500 index had impact to the financial sector stock index.

\section{CONCLUSION AND SUGGESTION}

\section{Conclusion}

According to these research results above, it could be concluded that:

1) Gross Domestic Product (GDP). Based on these IRF results, Fluctuate or shocks on GDP will be responded negatively in the long term by these financial sector stock index based on the FEVD results, GDP had contribution of 3.66 percent in changed of financial sector's stock price index.

2) Inflation. Based on these IRF results said that fluctuate or shocks on inflation will be responded negatively by financial sector's stock index according to FEVD results, inflation had contributed 2.12 percent in changed of financial sector's stock price index.

3) BI interest rates. According to IRF results, fluctuate or shocks on BI interest rates will be responded positively in the long term by financial sector's stock index and based on FEVD results, BI interest rates had contributed of 8.58 percent in changed of financial sector's stock index.

4) Exchange rate. Based on these IRF results, Fluctuate or shocks on exchange rate will be responded positively in the long term by financial sector stock index and based on FEVD results, the exchange rate had contribution of 0.52 percent in changed of financial sector's stock index.

5) The Fed's interest rate. According to these IRF results, fluctuate or shocks on Fed's interest rate will be responded positively in the long term by financial sector stock index and based on FEVD results, the Fed interest rate had contributed of 0.45 percent in changed of financial sector stock index.

6) Gold price. According to these IRF results, fluctuate or shocks on gold price will be responded negatively in the long term by financial sector stock index and based on FEVD results, gold price had contributed of 1.70 percent in changed of financial sector stock index.

7) Oil prices. According to these IRF results, fluctuate or shocks on oil prices will be responded negatively in the long term by financial sector stock index and based on FEVD results, oil prices had contributed of 1.63 percent in changed of financial sector stock index.

8) S\&P 500 Index. According to these IRF results, fluctuate or shocks on S\&P 500 index will be responded negatively in the long term by financial sector stock index and based on FEVD results, S\&P 500 index had contributed of 0.79 percent in changed of financial sector stock index. 


\section{Suggestions}

Based on these conclusions above, the authors need to submit an advise for further researcher, such as:

1) Investors and potential investors in Indonesian capital market, especially those who want to invest, particularly in financial sector, needs to consider those macro variables, such as GDP, inflation, Bank Indonesia interest rates, exchange rates, Fed interest rate, gold prices, oil prices and S\&P 500 index. This should be noticed because the shocks from these variables have long-term impact;

2) This research has limited to determinants of banking sector stock price index with period of 5 years and 8 months only. Thus, further research was expected to use other sectors or industries which are different, for example the manufacturing sector as dependent variable so as to produce different types of research and expand the scope of analysis;

3) Future research was expected to use different independent variables, such as exports, imports, state revenue or taxes and the money supply to see the implications of same or different sectors;

4) As for choosing the research period time it is hoped that further research will selected the right time, according to Economic momentum which occurs. This intended to see the sensitivity of each independent variable to dependent variable which is more in-depth and specific.

\section{REFERENCES}

Asianto A., Siregar H. Mualana TNA. (2019). The Value at Risk of Selling Option on Crude Oil West Texas Intermediate. School of Business, Bogor Agricultural University (IPB). Jurnal VaR of Sell Opt-WTI-Etikonomi Vol. 18-1.

Amarasinghe, AAMD. (2015). Dynamic Relationship between Interest Rate and Stock Price: Empirical Evidence from Colombo Stock Exchange. International Journal of Business and Social Science, vol. 6, no. 4, pp. 92-97.

Bank Indonesia. (2016). Metadata Suku Bunga Bank Indonesia.

Fama, Eugene F. (1970). Efficient Capital Markets: A Review of Theory and Empirical Work. The Journal of Finance, vol. 2 no.2, pp. 383-417.

Irwanto, Andry, I Made Narsa. (2016). Ketepatan Pasar Modal dalam Memprediksi Kondisi Ekonomi (Studi di Bursa Efek Indonesia). Berkala Akuntansi dan Keuangan Indonesia, vol. 1, no. 2, pp. 163-175.

Kewal, Suramaya Suci. (2012). Pengaruh Inflasi, Suku Bunga, Kurs, dan Pertumbuhan PDB terhadap Indeks Harga Saham Gabungan. Jurnal Economia, vol. 8, no. 1, pp. 53-64.

Maulana, Panji Rizki, Ubud Salim, Siti Aisjah. (2015). Determinan Harga Saham Perbankan yang Terdaftar (2009-2012) di Bursa Efek Indonesia. Jurnal Akuntansi Multiparadigma, Vol. 6, No. 2, pp. 185-200.

Misgiyanti, Idah Zuhroh (2009). Pengaruh Suku Bunga Luar Negeri Federal Reserve (The Fed), Nilai Tukar Rupiah/US \$ dan Inflasi terhadap Indeks Harga Saham Gabungan di Bursa Efek Indonesia Periode 2006-2008. Jurnal Ekonomi Pembangunan, Vol. 7, No. 1, pp. 19-32. 
Miyanti, Gusti Ayu Diah Akua, Luh Putu Wiagustini. (2018). Pengaruh Suku Bunga The Fed, Harga Minyak dan Inflasi terhadap Indeks Harga Saham Gabungan (IHSG) di Bursa Efek Indonesia. E-Jurnal Ekonomi dan Bisnis Universitas Udayana, 7.5, pp. 1261-1288.

Nanga, Muana. (2005). Makro Ekonomi: Teori, Masalah, dan Kebijakan. Rajawali Pers, Jakarta.

Oktarina, Dian. (2016). Pengaruh Beberapa Indeks Saham Global dan Indikator Makroekonomi terhadap Pergerakan IHSG. Journal of Business and Banking, vol. 5, no. 2, pp. 163-182.

Satyatama, Hastra Reza, Riwi Sumantyo. (2017). Performance Analysis of Indonesia's Mining Sector Price Index. Jurnal Ilmu Ekonomi, vol. 6, no.2, pp. 357-370.

Sihombing, Pardomuan, Rizal. (2014). Pengaruh Indeks Saham Global dan Kondisi Makro Indonesia terhadap Indeks Harga Saham Gabungan Bursa Efek Indonesia. Media Ekonomi, vol. 22, no. 2, 133-150.

Widodo, Rahmad, Musriha, Enny Istanti. (2017). Pengaruh Suku Bunga SBI, Standart \& Poor's 500 dan Indeks Nikkei 225 terhadap Indeks Harga Saham Gabungan (IHSG) di Bursa Efek Indonesia (BEI). Jurnal Manajemen Branchmark, vol. 3, issue 3, pp. 9851000 . 